\title{
Seroepidemiology of Herpes Simplex virus type I and 2 in Western and Southern Switzerland in adults aged 25-74 in 1992-93 : a population-based study
}

\author{
Dominique Bünzli1 ${ }^{1}$, Vincent Wietlisbach ${ }^{3}$, Fabrizio Barazzoni ${ }^{4}$, \\ Roland Sahli ${ }^{1}$ and Pascal RA Meylan*1,2
}

\begin{abstract}
Address: ${ }^{1}$ Institut de Microbiologie, CHUV, Lausanne, Switzerland, ${ }^{2}$ Service des Maladies Infectieuses, CHUV, Lausanne, Switzerland, ${ }^{3}$ Institut Universitaire de Médecine Sociale et Préventive, Lausanne, Switzerland and ${ }^{4}$ Ente Ospedaliero Cantonale, Bellinzona, Switzerland

Email: Dominique Bünzli - dobunzli@swissonline.ch; Vincent Wietlisbach - Vincent.Wietlisbach@inst.hospvd.ch;

Fabrizio Barazzoni - fabrizio.barazzoni@eoc.ch; Roland Sahli - roland.sahli@hospvd.ch; Pascal RA Meylan* - pascal.meylan@chuv.hospvd.ch

* Corresponding author
\end{abstract}

Published: 17 March 2004

BMC Infectious Diseases 2004, 4:10

This article is available from: http://www.biomedcentral.com/I47/-2334/4//0

(C) 2004 Bünzli et al; licensee BioMed Central Ltd. This is an Open Access article: verbatim copying and redistribution of this article are permitted in all media for any purpose, provided this notice is preserved along with the article's original URL.
Received: 23 June 2003

Accepted: 17 March 2004

\begin{abstract}
Background: Genital herpes is one of the most prevalent sexually-transmitted diseases, and accounts for a substantial morbidity. Genital herpes puts newborns at risk for very severe disease and also increases the risk of horizontal HIV transmission. It thus stands as an important public health problem. The recent availability of type-specific gG-based assays detecting $\lg G$ against HSV$\mathrm{I}$ and HSV-2 allows to establish the prevalence of each subtype. Worldwide, few data have been published regarding the seroprevalence in general populations of HSV-2, the major causative agent for genital herpes, while no data exist regarding the Swiss population.
\end{abstract}

Methods: To evaluate the prevalence of $\lg G$ antibodies against HSV-I and HSV-2 in Switzerland, we used a population-based serum repository from a health examination survey conducted in the Western and Southern area of Switzerland in 1992-93. A total of 3, I 20 sera were analysed by typespecific gG-based ELISA and seroprevalence was correlated with available volunteers characteristics by logistic regression.

Results: Overall, seroprevalence rates were $80.0 \pm 0.9 \%$ (SE, 95\% Cl: 78.I-8I.8) for HSV-I and $19.3 \pm 0.9 \%$ (SE, 95\% Cl: 17.6-2I.I) for HSV-2 in adults 35-64 year old. HSV-I and HSV-2 seroprevalence increased with age, with a peak HSV-2 seroprevalence in elderly gentlemen, possibly a seroarcheological evidence of sexually transmitted disease epidemics during World War II. Risk factors for HSV-2 infection included female sex, marital status other than married, and size of town of residence larger than 1500 inhabitants. Unexpectedly and conversely to HSV-I, HSV-2 seroprevalence increased with educational level. HSV-2 infection was less prevalent among HSV-I infected individuals when compared to HSV-I uninfected individuals. This effect was most apparent among women at high risk for HSV-2 infection.

Conclusions: Our data demonstrate that by the early nineties, HSV-2 had spread quite largely in the Swiss population. However, the epidemiology of HSV-2 in Switzerland presents paradoxical characteristics, e.g. positive correlation with education level, that have not been observed elsewhere. 


\section{Background}

While Herpes simplex virus type 1 (HSV-1) is a virus transmitted in casual contacts during childhood and in sexual contacts, leading to very high prevalence rate, HSV-2 is mostly transmitted sexually to cause genital herpes [1]. HSV-2 seroprevalence ranges from a few percent to $80 \%$ depending on risk factors such as age, sexual promiscuity, race and socio-economic level [1-3]. Up to half of primary genital herpes episodes are caused by HSV-1, especially in some European countries such as Great Britain, Scandinavia, and Switzerland [4-8]. However HSV-2 is more prone to cause frequent recurrence of genital symptoms $[9,10]$ as well as asymptomatic recurrences compared to HSV-1, $[11,12]$ leading to the majority of transmission events [13]. Hence, HSV-2 remains the major player in genital herpes.

As a cause for substantial suffering due to recurrent clinical herpes [9], for catastrophic neonatal infection [14] and as a cofactor favoring HIV infection [15], the public health significance of genital herpes cannot be overestimated.

The most recent data available in the United States demonstrate a 30\% increase of HSV-2 seroprevalence as documented by NHANES II and III population surveys (197680 and 1988-94 respectively) over a 12 year period [16]. Considering the role of asymptomatic transmission, the frequency of unrecognised HSV-2 genital infection [16], the recent availability of type-specific serologic assays $[17,18]$, and the absence of an efficacious prophylactic vaccine [19], it comes as no surprise that in the US, proposals for an aggressive management of genital herpes have been made with the goal of interrupting genital herpes transmission. These proposals include mass screening, identification of asymptomatic carriers, and prophylactic treatment to prevent shedding $[20,21]$.

However, such a rise in HSV-2 seroprevalence has not been invariably observed in all locations $[22,23]$. In addition, seroprevalence rates in general populations vary quite dramatically, for instance from about $4 \%$ in the Spanish [24] and British [5] populations, to $15.6 \%$ in the French population [25] and up to $31 \%$ in rural Tanzania [26]. Even more dramatic variations of HSV-2 seroprevalence are observed according to established risk factors: age, sexual activity, socio-economic and racial background [2]. Thus, the estimation of the burden of HSV-2 infection in a particular region should be based on a random sample of its population, which may then serve as the basis for the evaluation of the need and the design of public health measures against the propagation of HSV-2 [16].

Regarding Switzerland, the only available data were provided by a study involving 151 low risk adult volunteers (aged 20-49) from a single city, demonstrating a prevalence of HSV-2 of $11 \%$, and suggesting that the overall prevalence in the Swiss general population might be high [27]. These results stressed the need for a more accurate estimation of this disease prevalence in our country.

The MONICA serum repository [28] was collected in 1992-3 in the framework of a population survey on cardiovascular risk factors conducted in two regions of Switzerland. As such, this repository offered the opportunity to estimate the prevalence rates of HSV-1 and HSV-2 infection in the Swiss adult population in the early nineties and to analyse these rates with respect to demographic and health-related variables.

\section{Methods \\ Study populations and sampling procedure}

The serum repository results from the third populationbased health examination survey conducted in Switzerland within the framework of the multicenter WHOMONICA (MONItoring trends and determinants in CArdiovascular disease) project in 1992-3 [28]. The survey was based on a random sample of the adult resident population of two Swiss regions, composed of the cantons of Vaud and Fribourg (mainly French-speaking, age range 25-74) on one hand and of the canton of Ticino (Italianspeaking, age range: 35 to 64 ) on the other hand. The twostage sampling procedure consisted first in drawing a random sample of communes (administrative divisions enclosing a village or a city and its surrounding territory) stratified by size (number of inhabitants) and, secondly in drawing a random sample of residents in the population files of the selected communes. The sampling fraction of communes were 51 out of 651 in Vaud-Fribourg and 25 out of 147 in Ticino. The population samples drafted in these two regions were of 3300 and 2000, of whom 1742 and 1510 persons respectively accepted to participate to the survey, corresponding to overall participation rates of $53 \%$ and $76 \%$ in the two areas. The participants were invited to attend a health examination in their commune of residence and to complete a self-administered questionnaire about their socio-demographic characteristics, dietary intakes, and lifestyle habits. In addition to anthropometric and blood pressure measurements, a venous blood sample was drawn from each subject for determination of blood lipid concentrations. The blood samples were allowed to clot at room temperature, centrifuged within two hours of harvest, and the serum transferred and stored at $-20^{\circ} \mathrm{C}$.

\section{Socio-economic indicators}

Educational level was categorized in four classes according to the highest degree the subjects had achieved and the age at which they completed their education, i.e. i) low : mandatory school only (age $\leq 16$ ); ii) medium: 
apprenticeship (age > 16); iii) high: secondary or professional school (age $>18$ ) and iv) very high: university (age $>22$ ).

\section{Serologic testing}

Samples were assayed by ELISA (HerpeSelect, Focus Technologies, Inc., Cypress, CA) for HSV-1 and HSV-2 IgG, according to the manufacturer instructions $[18,29]$. All samples with an Index Value between 0.8-1.2 (OD standardized using a reference serum set by the manufacturer to provide a cut off value arbitrarily given the Index value of 1) were tested again using the serum supernatant after centrifugation (15000 rpm during $5 \mathrm{~min}$ on a Eppendorf 5804 microfuge) and, if still undetermined, were resolved by immunoblot (HerpeSelect $1 \& 2$ Immunoblot, Focus Technologies, Inc).

\section{Statistical Analysis}

The data from the two study regions were pooled together for the overlapping age range (35-64) to increase statistical power. Complete data from the Vaud-Fribourg region extending to the age range 25-74 were used to analyze age patterns of HSV prevalence. In order to account for the regional differences in sampling fractions and participation rates in the MONICA survey, the HSV seroprevalence estimates were weighted by sex and age so as to be representative of the populations of the two study regions at the time of the survey (end of 1992). All the statistical analyses (i.e. estimation of prevalence rates and odd ratios, calculation of confidence intervals, logistic regression) were performed using the procedures adapted to weight survey data ("svy commands") in the Stata 6.0 (Stata Corp, College Station, TX) software.

The matching of the epidemiological data from the MONICA survey with the results of the serological testing for HSV-1 and HSV-2 antibodies allowed to analyse the prevalence of herpes across the different socio-demographic strata of the Swiss population and to identify factors influencing this prevalence. Variations of the seroprevalence rates between groups according to various characteristics (sex, age, marital status, education level, place of residence, etc) were first examined in cross-tabulations and bivariate logistic regression models. All variables were then entered into a multivariate logistic regression model in order to test whether they were predictors of the HSV status independently of each other. The contribution of a given explanatory variable was tested by the Wald test.

A classification tree analysis [30] was performed using the S-PLUS (StatSci, a Division of Math Soft, Seattle, USA) software in order to define population risk categories for HSV-2 on the basis of the different socio-demographic factors. This technique consists in successively splitting the whole set of subjects into increasingly homogeneous subsets, separating as far as possible those with a positive HSV-2 status from those with a negative HSV-2 status. Each split is conditioned by an optimal cut-off in the levels of a single factor and the process is continued as long as it is feasible or statistically significant. Tree-based models capture interactions between factors more easily than logistic regression models. This procedure generated subsets of subjects with increasing seroprevalence rates, i.e. reflecting different risk levels of acquiring HSV-2. Neither HSV-1 serostatus nor sex were used as discriminating factors because we wanted to analyse sex-specific differences in HSV-2 seroprevalence rates according to HSV-1 serostatus across these risk categories.

\section{Ethical considerations}

Serum samples had been drawn from the volunteers under a consent involving cardiovascular research but not explicitly for assays such as Herpes simplex antibodies. However, taking into account the potential relationship between Herpes simplex infection and atherosclerosis, the anonymisation of the database and the fact that the serum samples had been drawn 9 years before performing the study, the performance of HSV-1 and HSV-2 assays on this serum repository was authorised by the Institutional Review Board of the School of Medicine, CHUV, Lausanne.

\section{Results \\ Characteristics of the study population}

Of the 3235 serums available in the serum repository, 3120 could be matched in the MONICA database with one of the 3252 participants of the health examination survey. Fifteen samples had an identification number not corresponding to any of the participants probably because of transcription errors. On the other hand, 132 participants had no serum sample in the repository because of problems in serum collection $(\mathrm{n}=107$, missing values for blood lipids as well) or serum storage $(\mathrm{n}=25)$.

\section{Prevalence of antibodies against HSV-I and -2 infection}

Overall, for the pooled data concerning adults in the age range 35-64, the infection rate was $80.0 \%$ for HSV- 1 and $19.3 \%$ for HSV-2 (Tables 1 and 2). Infection rate was higher in women than in men for HSV-1 $(82.7 \%$ versus $77.2 \%, \mathrm{p}=0.004)$ and for HSV-2 (20.9\% and $17.7 \%, \mathrm{p}$ $=0.073$ ), but the difference was statistically significant for HSV-1 only (Tables 1 and 2). Seroprevalence rates were higher in the Ticino region than in the Vaud-Fribourg region for HSV-1 (87.7\% versus $77.0 \%, \mathrm{p}<0.001$ ), as was HSV-2 prevalence $(20.5 \%$ versus $18.9 \%, p=0.309)$, but statistical significance was reached for HSV-1 for both genders and for HSV-2 for females only (see also Table 5, multivariate analysis). 
Table I: Seroprevalence of HSV-I and HSV-2 according to various predictors in men aged 35-64, 1992-3, Vaud-Fribourg, Ticino

\begin{tabular}{|c|c|c|c|c|c|c|c|}
\hline & \multirow[b]{2}{*}{$\mathbf{n}$} & \multicolumn{3}{|c|}{ HSV-I } & \multicolumn{3}{|c|}{ HSV-2 } \\
\hline & & Rate \pm SE $(95 \% \mathrm{Cl})$ & $\begin{array}{l}\text { Odds Ratio } \\
\text { (95\% Cl) }\end{array}$ & $P$ value & Rate \pm SE $(95 \% \mathrm{Cl})$ & $\begin{array}{c}\text { Odds Ratio } \\
\text { (95\% Cl) }\end{array}$ & $P$ value \\
\hline \multicolumn{8}{|l|}{ Region } \\
\hline Vaud-Fribourga & $54 I$ & $73.5 \pm 1.9 \%(69.8-77.2)$ & $1.00(---)$ & --- & $\mid 8.1 \pm 1.7 \%(|4.9-2| .4)$ & $1.00(---)$ & --- \\
\hline Ticino & 693 & $87.0 \pm 1.3 \%(84.5-89.5)$ & $2.42(1.81-3.24)$ & $<0.001$ & $16.6 \pm 1.4 \%(13.8-19.4)$ & $0.90(0.67-1.21)$ & 0.487 \\
\hline \multicolumn{8}{|l|}{ Age group } \\
\hline $35-44$ & 479 & $70.8 \pm 2.4 \%(66.0-75.5)$ & $0.58(0.34-0.83)$ & 0.003 & $18.1 \pm 2.0 \%(|4|-22.1)$. & $1.01(0.68-1.50)$ & 0.956 \\
\hline $45-54^{a}$ & 433 & $80.8 \pm 2.3 \%(76.4-85.2)$ & $1.00(---)$ & --- & $17.9 \pm 2.1 \%(\mid 3.7-22.1)$ & $1.00(---)$ & --- \\
\hline $55-64$ & 322 & $82.3 \pm 2.6 \%(77.2-87.3)$ & $1.10(0.70-1.73)$ & 0.669 & $16.8 \pm 2.5 \%(|2.0-2| .6)$ & $0.92(0.59-1.45)$ & 0.730 \\
\hline \multicolumn{8}{|l|}{ Marital status } \\
\hline Single & 116 & $62.4 \pm 5.5 \%(51.5-73.2)$ & $0.45(0.27-0.74)$ & 0.002 & $21.5 \pm 4.6 \%(12.4-30.6)$ & $1.40(0.79-2.49)$ & 0.244 \\
\hline Marrieda & 1021 & $78.6 \pm 1.5 \%(75.6-81.6)$ & $1.00(---)$ & --- & $16.3 \pm 1.3 \%(13.7-18.9)$ & 1.00 & --- \\
\hline Sep/divorced & 86 & $76.7 \pm 5.4 \%(66.2-87.2)$ & $0.89(0.48-1.65)$ & 0.719 & $24.8 \pm 5.3 \%(14.4-35.3)$ & $1.69(0.94-3.06)$ & 0.081 \\
\hline Widowed & 11 & $78.6 \pm 15.2 \%(48.9-100.0)$ & $1.00(0.17-5.88)$ & 0.997 & $54.2 \pm 17.3 \%(20.3-88.1)$ & $6.07(1.53-24.11)$ & 0.011 \\
\hline \multicolumn{8}{|l|}{ Educational level } \\
\hline Low & 308 & $89.3 \pm 2.2 \%(84.9-93.6)$ & $2.56(1.52-4.19)$ & $<0.001$ & $17.2 \pm 2.6 \%(\mid 2.1-22.4)$ & $1.19(0.77-1.85)$ & 0.431 \\
\hline Mediuma $^{a}$ & 639 & $76.7 \pm 2.0 \%(72.8-80.6)$ & $1.00(---)$ & --- & $14.9 \pm 1.6 \%(\mid 1.7-18.0)$ & $1.00(---)$ & --- \\
\hline High & 140 & $67.3 \pm 4.4 \%(58.6-75.9)$ & $0.62(0.40-0.98)$ & 0.040 & $21.7 \pm 3.8 \%(14.2-29.1)$ & $1.58(0.95-2.63)$ & 0.076 \\
\hline Very high & 143 & $67.4 \pm 4.6 \%(58.4-76.4)$ & $0.63(0.39-1.00)$ & 0.050 & $26.0 \pm 4.3 \%(17.6-34.3)$ & $2.01(1.21-3.32)$ & 0.007 \\
\hline \multicolumn{8}{|l|}{ Size of commune } \\
\hline$<1500$ & 454 & $78.7 \pm 2.4 \%(74.1-83.3)$ & $1.14(0.78-1.68)$ & 0.485 & $15.2 \pm 2.0 \%(\mid 1.3-19.2)$ & $0.76(0.50-1.14)$ & 0.181 \\
\hline $1500-10^{\prime} 000^{a}$ & 454 & $76.3 \pm 2.4 \%(7 \mid .6-81.1)$ & $1.00(---)$ & --- & $19.2 \pm 2.2 \%(15.0-23.5)$ & $1.00(---)$ & --- \\
\hline$>10^{\prime} 000$ & 326 & $76.7 \pm 2.6 \%(71.5-81.8)$ & $1.01(0.69-1.50)$ & 0.941 & $18.6 \pm 2.4 \%(13.9-23.3)$ & $0.96(0.63-1.45)$ & 0.844 \\
\hline \multicolumn{8}{|l|}{ HSV-I-infected } \\
\hline $\mathbf{N o}^{a}$ & 234 & & & & $21.2 \pm 2.9 \%(15.5-26.9)$ & $1.00(---)$ & --- \\
\hline Yes & 1000 & & & & $16.7 \pm 1.4 \%(13.9-19.4)$ & $0.74(0.50-1.1 \mathrm{I})$ & 0.143 \\
\hline Total & 1234 & $77.2 \pm 1.4 \%(74.5-80.0)$ & --- & --- & $17.7 \pm 1.3 \%(\mid 5.2-20.2)$ & --- & --- \\
\hline
\end{tabular}

a reference strata for the logistic analysis

Table 2: Seroprevalence of HSV-I and HSV-2 according to various predictors in women aged 35-64, 1992-3, Vaud-Fribourg, Ticino

\begin{tabular}{|c|c|c|c|c|c|c|c|}
\hline & \multirow[b]{2}{*}{$\mathbf{n}$} & \multicolumn{3}{|c|}{ HSV-I } & \multicolumn{3}{|c|}{ HSV-2 } \\
\hline & & Rate \pm SE $(95 \% \mathrm{Cl})$ & $\begin{array}{l}\text { Odds Ratio } \\
\text { (95\% CI) }\end{array}$ & $P$ value & Rate \pm SE $(95 \% \mathrm{Cl})$ & $\begin{array}{l}\text { Odds Ratio } \\
\text { (95\% Cl) }\end{array}$ & $P$ value \\
\hline \multicolumn{8}{|l|}{ Region } \\
\hline Vaud-Fribourga & 565 & $80.4 \pm 1.7 \%(77.2-83.7)$ & $1.00(---)$ & --- & $19.6 \pm 1.7 \%(16.3-22.9)$ & $1.00(--)$ & --- \\
\hline Ticino & 743 & $88.4 \pm 1.2 \%(86.1-90.7)$ & $1.86(1.37-2.53)$ & $<0.001$ & $24.3 \pm 1.6 \%(21.2-27.4)$ & $1.31(1.00-1.72)$ & 0.047 \\
\hline \multicolumn{8}{|l|}{ Age group } \\
\hline $35-44$ & 490 & $78.8 \pm 2.1 \%(74.7-83.0)$ & $0.72(0.49-1.06)$ & 0.097 & $19.5 \pm 2.0 \%(15.7-23.3)$ & $0.83(0.58-1.18)$ & 0.292 \\
\hline $45-54^{a}$ & 472 & $83.8 \pm 2.0 \%(79.8-87.8)$ & $1.00(---)$ & --- & $22.6 \pm 2.2 \%(18.2-27.0)$ & $1.00(---)$ & --- \\
\hline $55-64$ & 346 & $86.7 \pm 2.3 \%(82.2-91.3)$ & $1.26(0.77-2.07)$ & 0.347 & $20.9 \pm 2.6 \%(15.8-26.0)$ & $0.90(0.61-1.34)$ & 0.609 \\
\hline \multicolumn{8}{|l|}{ Marital status } \\
\hline Single & 106 & $8 \mathrm{I} .1 \pm 4.7 \%(72.0-90.3)$ & $0.87(0.46-1.63)$ & 0.658 & $27.3 \pm 5.3 \%(16.9-37.8)$ & $1.77(1.02-3.10)$ & 0.044 \\
\hline Married $^{a}$ & 984 & $83.2 \pm 1.4 \%(80.5-86.0)$ & $1.00(---)$ & --- & $\mid 7.5 \pm 1.4 \%(\mid 4.8-20.2)$ & $1.00(---)$ & --- \\
\hline
\end{tabular}


Table 2: Seroprevalence of HSV-I and HSV-2 according to various predictors in women aged 35-64, 1992-3, Vaud-Fribourg, Ticino

\begin{tabular}{|c|c|c|c|c|c|c|c|}
\hline Sep/divorced & 142 & $77.2 \pm 4.1 \%(69.1-85.2)$ & $0.68(0.4|-| .12)$ & 0.131 & $35.1 \pm 4.5 \%(26.3-43.9)$ & $2.55(1.66-3.92)$ & $<0.001$ \\
\hline Widowed & 76 & $90.0 \pm 4.1 \%(81.9-98.0)$ & I.8I (0.72-4.53) & 0.205 & $28.6 \pm 6.1 \%(16.7-40.5)$ & $1.89(1.02-3.48)$ & 0.042 \\
\hline \multicolumn{8}{|c|}{ Educational level } \\
\hline Low & $47 \mid$ & $89.2 \pm 1.8 \%(85.6-92.7)$ & $1.75(1.13-2.72)$ & 0.012 & $16.5 \pm 2.0 \%(12.6-20.4)$ & $0.65(0.45-0.92)$ & 0.014 \\
\hline Mediuma & 637 & $82.4 \pm 1.8 \%(78.9-85.9)$ & $1.00(---)$ & --- & $23.4 \pm 1.9 \%(19.7-27.2)$ & $1.00(---)$ & --- \\
\hline High & 138 & $74.4 \pm 4.1 \%(66.3-82.5)$ & $0.62(0.38-1.01)$ & 0.055 & $23.6 \pm 4.0 \%(|5.7-3| .4)$ & $1.01(0.62-1.64)$ & 0.974 \\
\hline Very high & 59 & $63.0 \pm 7.1 \%(49.1-76.9)$ & $0.36(0.19-0.69)$ & 0.002 & $18.2 \pm 4.9 \%(8.6-27.8)$ & $0.73(0.37-1.43)$ & 0.356 \\
\hline \multicolumn{8}{|c|}{ Size of commune } \\
\hline$<1500$ & 437 & $80.3 \pm 2.3 \%(75.8-84.8)$ & $0.54(0.35-0.84)$ & 0.006 & $15.7 \pm 2.0 \%(\mid 1.8-19.5)$ & $0.64(0.44-0.93)$ & 0.020 \\
\hline $1500-10^{\prime} 000^{a}$ & 495 & $88.2 \pm 1.7 \%(84.9-91.6)$ & $1.00(---)$ & --- & $22.5 \pm 2.1 \%(18.3-26.7)$ & $1.00(---)$ & --- \\
\hline$>10^{\prime} 000$ & 376 & $79.1 \pm 2.4 \%(74.4-83.8)$ & $0.50(0.33-0.78)$ & 0.002 & $24.1 \pm 2.5 \%(19.3-29.0)$ & $1.09(0.76-1.56)$ & 0.629 \\
\hline \multicolumn{8}{|c|}{ HSV-I-infected } \\
\hline $\mathbf{N o}^{\mathbf{a}}$ & 197 & & & & $29.0 \pm 3.6 \%(21.9-36.0)$ & $1.00(---)$ & --- \\
\hline Yes & 1111 & & & & $19.3 \pm 1.4 \%(16.6-21.9)$ & $0.59(0.40-0.86)$ & 0.006 \\
\hline Total & 1308 & $82.7 \pm 1.2 \%(80.2-85.1)$ & --- & --- & $20.9 \pm 1.3 \%(18.4-23.5)$ & --- & --- \\
\hline
\end{tabular}

a reference strata for the logistic analysis

Table 3: Age-dependent seroprevalence of HSV-I and HSV-2, Vaud-Fribourg, 1992-3, Men

\begin{tabular}{|c|c|c|c|c|c|c|c|}
\hline \multirow[b]{2}{*}{ Age group } & \multicolumn{4}{|c|}{ HSV-I } & \multicolumn{3}{|c|}{ HSV-2 } \\
\hline & $\mathbf{n}$ & $\begin{array}{l}\text { Rate seropositive } \\
\text { (士SE, 95\% CI) }\end{array}$ & $\begin{array}{l}\text { Odds Ratio } \\
(95 \% \mathrm{Cl})\end{array}$ & $P$ value & $\begin{array}{l}\text { Rate seropositive } \\
\text { (士SE, 95\% CI)) }\end{array}$ & $\begin{array}{l}\text { Odds Ratio } \\
\text { (95\% Cl) }\end{array}$ & $P$ value \\
\hline $25-34$ & 189 & $58.2 \pm 3.6 \%(51.2-65.3)$ & $0.39(0.25-0.62)$ & $<0.001$ & $10.6 \pm 2.2 \%(6.2-15.0)$ & $0.53(0.29-0.96)$ & 0.037 \\
\hline $35-44$ & 223 & $66.4 \pm 3.2 \%(60.2-72.6)$ & $0.56(0.36-0.87)$ & 0.010 & $18.4 \pm 2.6 \%(\mid 3.3-23.5)$ & $1.01(0.61-1.67)$ & 0.978 \\
\hline $45-54^{a}$ & 186 & $78.0 \pm 3.0 \%(72.0-83.9)$ & $1.00(--)$ & -- & $18.3 \pm 2.8 \%(12.7-23.8)$ & $1.00(---)$ & --- \\
\hline $55-64$ & 132 & $78.8 \pm 3.6 \%(71.8-85.8)$ & $1.05(0.6 \mathrm{I}-1.8 \mathrm{I})$ & 0.860 & $17.4 \pm 3.3 \%(10.9-23.9)$ & $0.94(0.52-1.70)$ & 0.845 \\
\hline $65-74$ & 85 & $78.8 \pm 4.5 \%(70.1-87.6)$ & $1.05(0.56-1.97)$ & 0.873 & $29.4 \pm 5.0 \%(19.7-39.2)$ & $1.86(1.02-3.40)$ & 0.042 \\
\hline Total & 815 & $69.9 \pm 1.6 \%(66.8-73.0)$ & --- & -- & $17.3 \% \pm 1.3 \%(14.7-19.9)$ & --- & --- \\
\hline
\end{tabular}

areference strata for the logistic analysis

Table 4: Age-dependent seroprevalence of HSV-I and HSV-2, Vaud-Fribourg, 1992-3, Women

\begin{tabular}{|c|c|c|c|c|c|c|c|}
\hline \multirow[b]{2}{*}{ Age group } & \multicolumn{4}{|c|}{ HSV-I } & \multicolumn{3}{|c|}{ HSV-2 } \\
\hline & $\mathbf{n}$ & $\begin{array}{c}\text { Rate seropositive } \\
\text { (士SE, 95\% CI) }\end{array}$ & $\begin{array}{l}\text { Odds Ratio } \\
\text { (95\%Cl) }\end{array}$ & $P$ value & $\begin{array}{c}\text { Rate seropositive } \\
\text { (士SE, 95\% CI) }\end{array}$ & $\begin{array}{l}\text { Odds Ratio } \\
\text { (95\%Cl) }\end{array}$ & $P$ value \\
\hline $25-34$ & 204 & $69.1 \pm 3.2 \%(62.8-75.5)$ & $0.54(0.35-0.85)$ & 0.008 & $12.2 \pm 2.3 \%(7.7-16.8)$ & $0.47(0.28-0.8 \mathrm{I})$ & 0.006 \\
\hline $35-44$ & 237 & $77.2 \pm 2.7 \%(71.9-82.6)$ & $0.81(0.5 \mathrm{I}-\mathrm{I} .29)$ & 0.376 & $17.3 \pm 2.5 \%(\mid 2.5-22.1)$ & $0.7 \mid(0.44-1.14)$ & 0.154 \\
\hline $45-54^{a}$ & 202 & $80.7 \pm 2.8 \%(75.2-86.1)$ & $1.00(---)$ & --- & $22.8 \pm 3.0 \%(17.0-28.6)$ & $1.00(---)$ & --- \\
\hline $55-64$ & 126 & $84.9 \pm 3.2 \%(78.6-91.2)$ & $1.35(0.74-2.46)$ & 0.332 & $19.0 \pm 3.5 \%(12.2-25.9)$ & $0.80(0.46-1.39)$ & 0.426 \\
\hline $65-74$ & 100 & $84.0 \pm 3.7 \%(76.8-91.2)$ & $1.26(0.66-2.39)$ & 0.486 & $17.0 \pm 3.8 \%(9.6-24.4 \%)$ & $0.69(0.37-1.29)$ & 0.249 \\
\hline Total & 869 & $77.9 \pm 1.4 \%(75.2-80.7)$ & --- & --- & $17.3 \pm 1.3 \%(14.8-19.8)$ & --- & --- \\
\hline
\end{tabular}

areference strata for the logistic analysis 


\section{HSV seroprevalence and variables other than age}

For sociodemographic variables other than age, the association with HSV infection was analyzed using the pooled data of both regions within the age range 35-64. Sex-specific seroprevalence rates and unadjusted odds-ratios are shown in Tables 1 and 2. Adjusted odds ratios, 95\% confidence intervals and $\mathrm{p}$ values resulting from multivariate logistic regression models of $\mathrm{HSV}-2$ seroprevalence are shown on Table 5.

\section{HSV seroprevalence and marital status}

Marital status was associated with HSV infection in both sexes. In males, a lower HSV-2 seroprevalence was observed in married subjects compared to all other categories, significantly so in widowed subjects as compared to married subjects (Table 1 ). In females, HSV-2 seroprevalence was significantly higher in all categories (single, separated/divorced, or widowed) as compared to married subjects (Table 2). This observation was supported by the multivariate analysis (Table 5, $\mathrm{p}=0.013$ and 0.0004 for males and females respectively by the Wald test for the overall contribution of the marital status variable).

\section{HSV seroprevalence and socio-economic status}

Several socio-economic variables were collected in the MONICA survey: level of education, economic sector, employment grade and job qualification level. While similar trends in HSV seroprevalence rates were observed according to all these variables, the level of education showed the strongest association and was therefore selected for the present analysis.

The seroprevalence of HSV-1 decreased with increasing level of education in both genders (Tables 1 and 2). In contrast, the seroprevalence of HSV-2 increased significantly with increasing level of education (Tables 1 and 2). In males, the odds of being infected by HSV-2 were higher in subjects with high or very high education levels (see definition in material and methods) compared with subjects with low or medium education levels (Table 1), while in females, subjects with a low education level stood out with a low HSV-2 seroprevalence as compared with all higher education level subjects (Table 2). Again, this observation withstood the test of the multivariate analysis for males, and nearly so for females (Table 5, p = 0.045 and 0.064 for males and females respectively by the Wald test for the overall contribution of the education level variable).

\section{HSV seroprevalence and size of place of residence}

As the two-stage sampling procedure of the MONICA survey consisted first in drawing a random sample of communes (see definition under method section) stratified according to their size, we could analyse the association between commune size and HSV seroprevalence. As seen in Tables 1 and 2, HSV-2 seroprevalence was lower among residents from small communes (<1500 inhabitants), when compared to residents from larger towns. This trend for a lower odd ratio of being infected by HSV-2 was significant among females. Again, this conclusion was supported by the multivariate analysis (Table $5, \mathrm{p}=0.53$ and 0.02 for males and females respectively by the Wald test for the overall contribution of the place of residence variable).

\section{Interaction between HSV-I and HSV-2 infection}

HSV-1-seropositive individuals had a lower HSV-2 seroprevalence rate compared to HSV-1-uninfected subjects, and this difference was statistically significant in women and of borderline significance in men (Tables 1 and 2). The inverse association between HSV-1 and HSV-2 serological status persisted after adjustment for age and the other sociodemographic variables in females (Table 5, $\mathrm{p}=$ 0.30 and 0.006 for males and females respectively by the Wald test for the overall contribution of the HSV-1 serostatus variable). The potential role of sex and HSV-1 status in protection against HSV-2 transmission was more closely examined in population risk groups for HSV-2 infection defined by classification tree analysis (see methods). Young adults 25 to 34 years old and living alone formed the lowest risk group (HSV-2 seroprevalence: $3.9 \%$ ) and those living with a partner formed the second lowest $(13.3 \%)$. The highest risk group comprised the adults aged 35 years and more who were separated, divorced or widowed (31.6\%) while those single or married had an intermediate risk depending of their educational level (less than high: $17.0 \%$; high or very high: $23.6 \%)$. Figure 1 shows the HSV-2 seroprevalence rate in these five groups according to sex and HSV-1 serostatus. The protective effect of HSV-1 infection against HSV-2 was mostly contributed by women in the high risk group for HSV-2 infection with an odds ratio of 0.37 (95\% confidence interval $0.19-0.75 ; \mathrm{p}=0.005$ ).

\section{HSV seroprevalence in pregnant women}

Women in the MONICA study were asked whether they had been pregnant within the twelve months before participating to the study. Among those 55 answering that they had been, $72.7 \%$ were seropositive for HSV-1 and 9.1\% for HSV-2.

\section{HSV prevalence and age}

Since a larger age range of participants was sampled in the Vaud-Fribourg region, the relationship between age and HSV seroprevalence was analysed in detail in this region. Of note, similar age patterns in HSV-1 and -2 prevalence were observed in the Ticino sample from age 35 to 64 . As shown in Tables 3 and 4, the prevalence of HSV-1 infection was high even among the youngest subjects (25-34 year old, 58.2\% among males and 69.1 \% among 

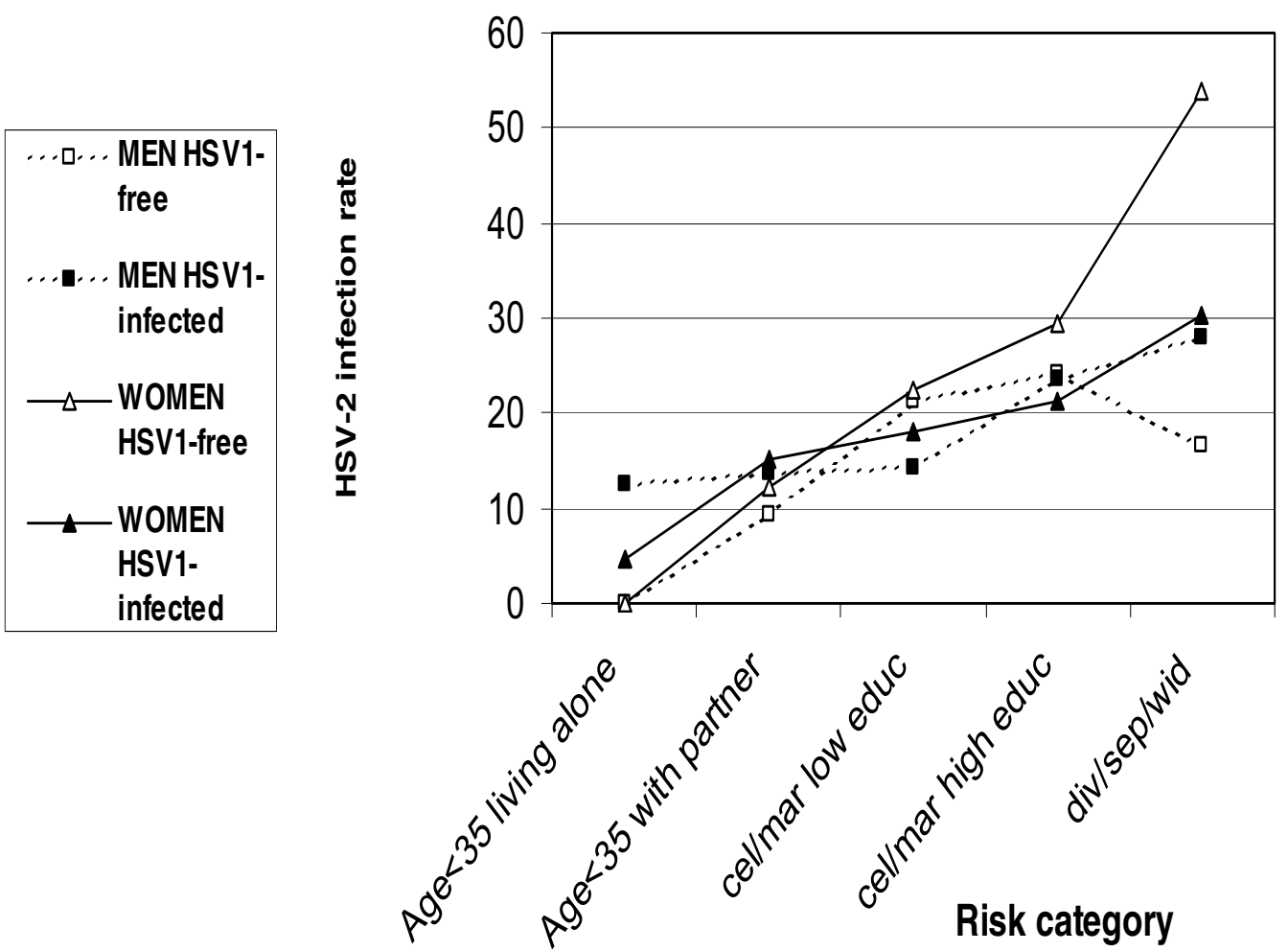

\section{Figure I}

HSV-2 seroprevalence by sex and HSV-I serostatus in the Swiss population across five strata from the lowest to the highest risk for HSV-2 infection defined by decision analysis using predictors identified by logistic analysis (Aged less than 35 , living alone; aged less than 35 living with a partner; single or married with a low level of education; single or married with a high level of education; divorced or separated or widowed)

females). This prevalence increased with age. The prevalence of HSV-2 was respectively $10.6 \%$ among males and $12.2 \%$ among females 25-34 year old. In middle-aged adults (35-64 years old) of both gender, the HSV-2 seroprevalence rates reached a plateau at $18-20 \%$. In the elderly (65-74 years old), men had a significantly higher seroprevalence rate than their middle-aged counterparts.

\section{Discussion}

In the present study, data regarding the prevalence of HSV-1 and, more importantly HSV-2, have been obtained for the first time from a multistage probability sample of the general population in two regions of Switzerland. Generating a population-based repository is a complex and costly task; however only such a repository provides information on the prevalence and allows to analyse predictors for infection in the general population. Indeed, few studies of HSV seroprevalence have used such repositories $[16,25,26]$. Most of the published seroprevalence data have been from selected groups of populations [2].

The present serum repository was harvested in the framework of a population-based study of cardiovascular risk factors: as such, our study has several limitations. First, the low participation rate (53\%) of the population survey in the Vaud-Fribourg region challenges the representativeness of the data. While lower than participation in a similar major study, the availability of the majority of the sera led to $51 \%$ of the sample having a serostatus determined, 
Table 5: Multivariate logistic analysis of the risk of HSV-2 infection in males and females, 1992-3, Vaud-Fribou rg, Ticino

\begin{tabular}{|c|c|c|c|c|c|c|}
\hline & \multicolumn{3}{|c|}{ males } & \multicolumn{3}{|c|}{ females } \\
\hline & Odds Ratio & $95 \% \mathrm{Cl}$ & $P$ value & Odds Ratio & $95 \% \mathrm{Cl}$ & $P$ value \\
\hline \multicolumn{7}{|l|}{ Region } \\
\hline Vaud-Fribourga & 1.00 & --- & --- & 1.00 & --- & --- \\
\hline Ticino & 0.97 & $0.70-1.34$ & 0.85 & 1.53 & $1.14-2.05$ & 0.004 \\
\hline \multicolumn{7}{|l|}{ Age group } \\
\hline $35-44$ & 0.96 & $0.64-1.43$ & 0.83 & 0.79 & $0.55-1.12$ & 0.19 \\
\hline $45-54^{a}$ & 1.00 & --- & --- & 1.00 & --- & --- \\
\hline $55-64$ & 0.89 & $0.56-1.40$ & 0.61 & 0.87 & $0.57-1.32$ & 0.52 \\
\hline \multicolumn{7}{|l|}{ Marital status } \\
\hline Single & 1.24 & $0.69-2.23$ & 0.48 & 1.57 & $0.89-2.79$ & 0.12 \\
\hline Marrieda & 1.00 & --- & -- & 1.00 & --- & -- \\
\hline Sep/divorced & 1.70 & $0.93-3.13$ & 0.08 & 2.35 & $1.52-3.63$ & $<0.001$ \\
\hline Widowed & 7.23 & $1.85-28.3$ & 0.005 & 2.10 & $1.08-4.06$ & 0.027 \\
\hline \multicolumn{7}{|l|}{ Educational level } \\
\hline Low & 1.25 & $0.80-1.97$ & 0.329 & 0.63 & $0.44-0.91$ & 0.015 \\
\hline Medium $^{a}$ & 1.00 & --- & --- & 1.00 & --- & --- \\
\hline High & 1.56 & $0.94-2.61$ & 0.08 & 0.99 & $0.61-1.63$ & 0.98 \\
\hline Very high & 2.01 & $1.19-3.39$ & 0.009 & 0.63 & $0.29-1.33$ & 0.22 \\
\hline \multicolumn{7}{|l|}{ Size of commune } \\
\hline$<1500$ & 0.79 & $0.52-1.20$ & 0.27 & 0.61 & $0.4|-0.9|$ & 0.015 \\
\hline $1500-10^{\prime} 000^{a}$ & 1.00 & --- & --- & 1.00 & --- & --- \\
\hline$>10^{\prime} 000$ & 0.93 & $0.61-1.44$ & 0.77 & 1.03 & $0.7|-| .5 \mid$ & 0.86 \\
\hline \multicolumn{7}{|l|}{ HSV-I-infected } \\
\hline $\mathbf{N o}^{a}$ & 1.00 & --- & --- & 1.00 & --- & --- \\
\hline Yes & 0.79 & $0.52-1.23$ & 0.30 & 0.58 & $0.39-0.85$ & 0.006 \\
\hline
\end{tabular}

a reference strata for the logistic analysis. Odds ratios for a given variable are adjusted for the other variables in the Table

versus $60.2 \%$ in the NHANES III study [16]. In addition, the results have been weighted by sex and age to adjust for participation bias. Second, because of its limited age range ( 25 to 74 ), the study does not provide information about the HSV prevalence rates among children and adolescents. Third, the serum repository was harvested during a single cross-sectional survey in the early nineties and time trends in HSV seroprevalence in Switzerland cannot be monitored using these data. Fourth, sampling occurred in only two (French and Italian-speaking) regions. Recent data from the Zurich area using selected samples of population however seem to indicate a similar high HSV-2 seroprevalence in the German-speaking area (S. Lautenschlager, personal communication). Finally, the questionnaire did not include questions regarding sexual behaviour, precluding HSV prevalence analysis for these variables.

Nevertheless, our study provides data interesting to compare in particular with HSV-1 and -2 seroprevalence data gathered at about the same time in the US [16,31]. The figures obtained indicate that HSV-1 seroprevalence is very similar in Switzerland and in the US, and varies similarly according to age, and socio-economic variables. HSV-2 seroprevalence was somewhat lower in Switzerland, with a very similar effect of age on prevalence. In particular, in both populations, HSV-2 seroprevalence plateaus among middle age subjects from the third to the sixth decade of life. Interestingly, we observed a significant peak HSV-2 seroprevalence among elderly men (65-74 year old). These are subjects who were 15 to 24 year old during second world war (in 1942-43). Although we are unaware of any report of epidemics of sexually transmitted diseases in Switzerland at that time, it is well know that social disruption related to the war led to epidemics of STD elsewhere in the world, even in areas not directly involved in the conflict [32]. We therefore wonder whether this observation is a sero-archeological testimony of past changes in STD epidemiology, i.e. increased STD transmission in 
Swiss males fifty years before the survey was conducted. Why this would not be paralleled by a higher HSV-2 seroprevalence in females is unknown. However, this epidemic might have been preferentially transmitted to young males by a small core group of promiscuous females (e.g. prostitutes), which would be in number negligible compared to the general population. These females might also have been older than their sexual mates.

While HSV-2 seroprevalence was similar in the US in metropolitan and non urban counties [16], our study allowed to analyse the relationship between the size of the community (commune) of residence and HSV-2 seropositivity probably with a better resolution, and indeed demonstrates that at the time of the survey, individuals, and particularly women, living in rural areas and villages had a significantly reduced risk of HSV-2 infection.

The marital status had a similar influence on HSV-2 seroprevalence in the US and in Switzerland, suggesting that being separated/divorced or widowed is associated with a higher risk of infection. In contrast, the relationship between the socio-economic status, as expressed here by the education level, and HSV-2 seropositivity was opposite particularly in women in the Switzerland compared to the US, [16,33] and indeed to other countries [26,34]. This contrasts also with the inverse correlation between HSV-1 seroprevalence and socio-economic level in our study, a well known worldwide observation [2]. In the absence of information regarding determinants of exposure to sexually transmitted diseases in our database, we attempted to explain this paradoxical relationship, by resorting to data in an unrelated study performed in 1992-94 and assessing sexual behaviour in relation with sociodemographic variables in the same area (Western Switzerland) where our study was performed [35]. By reanalysing these data, we could evidence a positive correlation between education level and the life time number of sex partners which almost reached significance in female subjects. However, no such correlation was observed in males. In fact HSV-2 seroprevalence in our study is the result of transmission events that occurred over several decades before the serum collection. We interpret this observation as consistent with the hypothesis that in Switzerland, the liberal changes in the sexual behaviour that occurred during these decades have had more of an impact on the higher social strata. Interestingly, a similar trend, though not statistically significant, was recently described in a similar population-based study in France [25].

There is a continuum in the extent to which the spread of various STDs require very high rates of partner change and unprotected exposure to new partners [36]. Those that appear not to require high rates of partner change include HSV and HPV, are less concentrated in core groups, compared to bacterial STDs and more widely spread across a variety of socio-economic categories in populations [36]. Our data demonstrate that HSV-2 transmission is not only spread across a large variety of socio-economic categories, but, under given conditions, can concentrate among strata of populations usually at lower risk for STDs. The potential impact of our observation for the design of future prevention campaigns against STDs remains to be evaluated.

Among women who had been pregnant within twelve months before participating to the study, a little more than $9 \%$ were seropositive for HSV-2. They were thus at risk for genital herpes reactivation which carries a moderate risk for neonatal herpes [37]. On the other hand, close to $30 \%$ were seronegative for HSV-1, (the cause for about $50 \%$ of primary genital infections in Switzerland [6] and in Europe [7,38]) and 90\% were seronegative for HSV-2. These were thus at risk for a primary infection with the corresponding virus, a condition associated with a very high risk of neonatal herpes [37]. Our data thus provide an estimate of the population at risk for transmitting herpes to neonates. The actual incidence of neonatal herpes, which obviously varies with the rate for acquiring genital herpes during the third trimester of the pregnancy, a rate unknown in Switzerland, is currently determined in a countrywide prospective surveillance for neonatal herpes in the framework of the Swiss Pediatric Surveillance Unit.

Interaction between HSV-1 and HSV-2 remains a contentious issue. While it is generally admitted that patients with antibodies against HSV-1 and -2 are less likely to report a symptomatic genital herpes compared to patients with antibodies against HSV-2 only $[4,31,39]$, it is less clear whether antecedent HSV-1 infection can protect against subsequent HSV-2 acquisition. On one hand, cross-sectional studies using type-specific immunoassays have suggested that HSV-1 afford such a protection against subsequent HSV-2 infection, with an odd ratio of 0.7 among women attending family planning clinics [33], 0.78 in STD clinic attendees in California [40] and of 0.37 among Mexican prostitutes [41]. On the other hand, Xu et al. recently did not detect any significant protection neither in males nor in females in the general US population [31]. Similar data were reported recently in a population of Dutch STD clinic attendees, but the effect of HSV-1 on HSV-2 seropositivity rate was not analysed by sex [42]. This question has also been examined in the framework of prospective studies measuring the rate of HSV-2 transmission among serodiscordant couples. For instance, Mertz et al. [13] and Bryson et al. [43] evidenced a reduced rate of acquisition of HSV-2 infection in partners with previous HSV-1 infection as compared to HSV-1-uninfected partners. In contrast, no such protective effect of HSV-1 infec- 
tion was observed in pregnant women followed up prospectively [44] nor in HSV-2 seronegative sexually active participants to vaccine trials followed up prospectively [4].

As discussed recently [31], our study is admittedly not ideally suited for the study of the interaction between HSV-1 and HSV-2 because the data are cross-sectional. However, the difference in transmission mode between these two viruses results in HSV-1 preceding HSV-2 infection in a vast majority of cases [1], raising the possibility that antecedent HSV-1 infection may affect the susceptibility to, or the clinical expression of, HSV-2 infection. In the present study, HSV-1 seropositivity, when introduced in the multivariate logistic model, was associated with protection against HSV-2 infection, significantly so in women. However, for a protection against an infection to appear in a given population, this population has to be exposed. Using a decision analysis procedure, our study population was stratified by sex in five strata from the lowest to highest risk of acquiring HSV-2 infection, based on identified predictors other than HSV-1 seropositivity. The HSV-2 seropositivity rate was most strikingly reduced by HSV-1 seropositivity among women at the highest risk for HSV-2 infection.

Our results are thus consistent with the hypothesis that HSV-1 can prevent the acquisition of subsequent HSV-2 infection, and that this effect can be observed primarily among heavily exposed individuals, i.e. women highly exposed to HSV-2. Our observations may therefore explain why this protective effect is not universally observed in studies, depending on the study population exposure to HSV-2 infection. It is interesting to speculate why protection was observed only in women, reminiscent of the recent observation that a gD2-based vaccine demonstrated efficacy against infection limited to women).)[45]. First, the risk of transmission is higher from males to females than from females to males [46], making it easier to demonstrate protection in females than in males. Second, if protection is afforded by locally produced antibodies, then a mucous membrane covered by fluid containing antibodies such as the female genital mucosa is more likely to be protected than dry skin.

In addition, it is interesting to note the recent epidemiological trend for a reduced acquisition of HSV-1 during childhood, leading to an increasing sexual transmission of HSV-1 $[5,5,42]$. Therefore, assuming that HSV-1 precedes HSV-2 infection may become less valid an assumption in the future.

\section{Conclusions}

The present study provides a snapshot view of the epidemiology of Herpes simplex viruses in the Western and
Southern Swiss population in the early nineties. Assuming that the HSV-2 seroprevalence is similar throughout Switzerland as supported by recent studies in the Zurich area (S. Lautenschlager, personal communication), a projection suggests that countrywide, about 500'000 out of 2'633'000 people aged 35 to 64 in 1992 were infected by HSV-2. Risk factors for HSV-2 infections were identified as age, marital status (separated, divorced or widowed), residence in towns of middle to large size, and paradoxically, higher education in women. HSV-1 infection was associated with a lower HSV-2 seroprevalence particularly in HSV-2 exposed women. These data are important for the design of public health interventions aimed at preventing genital herpes spread. As sexual behavior surveillance studies have shown increased condom use without changes in other indicators, predicting the course of HSV2 epidemic beyond 1992-3 is difficult. Hence, follow up studies in Switzerland should include, in addition to surveillance for neonatal herpes, a repeated populationbased study to assess any temporal trend in HSV seroprevalence.

\section{List of abbreviations}

HSV: Herpes Simplex virus, HPV: human papilloma virus, MONICA: Monitoring trends and determinants in Cardiovascular disease, ELISA: enzyme linked immuno sorbent assay, STD: sexually-transmitted disease

\section{Competing interests}

Pascal Meylan is consultant for GlaxoSmithKline, which commercialises drugs for the prevention and treatment of herpes viruses infection. He has received fees and funding. Attracting attention to this problem may boost drug sales.

\section{Authors' contributions}

DB performed the serological testing, $\mathrm{VW}$ is responsible for the MONICA database and did the statistical analysis of the main study, FB organized the MONICA study in Ticino, RS supervised the serological testing and PRAM designed and coordinated the study and wrote the manuscript. All authors read and approved the final manuscript.

\section{Acknowledgements}

We thank the staff of the serology laboratory for invaluable help and Martin Rickenbach for help in providing access to the serum repository.

This work was supported by a grant from the Swiss Federal Office for Public Health \#01.000428, by GlaxoSmithKline Switzerland, Novartis Switzerland, Focus Technologies, Cypress, CA 90630 USA and by Pharma Consulting Marion Senn GMBH, Burgdorf, Switzerland

\section{References}

I. Whitley RC: Herpes Simplex Viruses. In Fields Virology Edited by: Knipe DM, Howley PM, Griffin DE, Lamb RA, Martin MA, Roizman B, Straus SE. Philadelphia, New York: Lippincott Williams\&Wilkins; 200I:246I-2509. 
2. Nahmias AJ, Lee FK, Beckman-Nahmias S: Sero-epidemiological and -sociological patterns of herpes simplex virus infection in the world. Scand J Infect Dis Suppl 1990, 69:19-36.

3. Cowan FM, Johnson AM, Ashley R, Corey L, Mindel A: Antibody to herpes simplex virus type 2 as serological marker of sexual lifestyle in populations. $B M]$ 1994, 309: I325-1329.

4. Langenberg AG, Corey L, Ashley RL, Leong WP, Straus SE: A prospective study of new infections with herpes simplex virus type I and type 2. Chiron HSV Vaccine Study Group. N Engl J Med 1999, 34I:| 1432-1438.

5. Vyse AJ, Gay NJ, Slomka MJ, Gopal R, Gibbs T, Morgan-Capner P, Brown DW: The burden of infection with HSV-I and HSV-2 in England and Wales: implications for the changing epidemiology of genital herpes. Sex Transm Infect 2000, 76:183-187.

6. Jolivet $P$, Sahli R, Meylan PR: Herpès génital: l'épidémie silencieuse? Médecine\&Hygiène 200I, 59:78I-789.

7. Lowhagen GB, Tunback P, Andersson K, Bergstrom T, Johannisson G: First episodes of genital herpes in a Swedish STD population: a study of epidemiology and transmission by the use of herpes simplex virus (HSV) typing and specific serology. Sex Transm Infect 2000, 76: 179-182.

8. Lafferty WE, Downey L, Celum C, Wald A: Herpes simplex virus type $I$ as a cause of genital herpes: impact on surveillance and prevention. J Infect Dis 2000, I 8 I: 1454-1457.

9. Lafferty WE, Coombs RW, Benedetti J, Critchlow C, Corey L: Recurrences after oral and genital herpes simplex virus infection. Influence of site of infection and viral type. $N$ Engl J Med 1987, 3 16: 1444-1449.

10. Benedetti J, Corey L, Ashley R: Recurrence rates in genital herpes after symptomatic first-episode infection [see comments]. Ann Intern Med 1994, I 2 1:847-854.

II. Wald A, Zeh J, Selke S, Ashley RL, Corey L: Virologic characteristics of subclinical and symptomatic genital herpes infections. $N$ Engl J Med 1995, 333:770-775.

12. Wald A, Zeh J, Selke S, Warren T, Ryncarz AJ, Ashley R, Krieger JN, Corey L: Reactivation of genital herpes simplex virus type 2 infection in asymptomatic seropositive persons. $N$ Engl J Med 2000, 342:844-850.

13. Mertz GJ, Benedetti J, Ashley R, Selke SA, Corey L: Risk factors for the sexual transmission of genital herpes. Ann Intern Med 1992 I 16:197-202.

14. Kimberlin DW, Lin CY, Jacobs RF, Powell DA, Frenkel LM, Gruber WC, Rathore M, Bradley JS, Diaz PS, Kumar M, Arvin AM, Gutierrez K, Shelton M, Weiner LB, Sleasman JW, de Sierra TM, Soong SJ, Kiell J, Lakeman FD, Whitley RJ, National Institute of Allergy and Infectious Diseases Collaborative Antiviral Study Group: Natural history of neonatal herpes simplex virus infections in the acyclovir era. Pediatrics 200I, 108:223-229.

15. Auvert B, Ballard R, Campbell C, Carael M, Carton M, Fehler G, Gouws E, MacPhail C, Taljaard D, Van Dam J, Williams B: HIV infection among youth in a South African mining town is associated with herpes simplex virus-2 seropositivity and sexual behaviour. AIDS 200I, 15:885-898.

16. Fleming DT, McQuillan GM, Johnson RE, Nahmias AJ, Aral SO, Lee FK, St Louis ME: Herpes simplex virus type 2 in the United States, 1976 to 1994. N Engl I Med 1997, 337: I I05-IIII.

17. Cowan FM: Testing for type-specific antibody to herpes simplex virus - implications for clinical practice. J Antimicrob Chemother 2000, 45(Suppl T3):9-13.

18. Ribes JA, Hayes M, Smith A, Winters JL, Baker DJ: Comparative performance of herpes simplex virus type 2-specific serologic assays from Meridian Diagnostics and MRL diagnostics. J Clin Microbiol 200 I, 39:3740-3742.

19. Straus SE, Corey L, Burke RL, Savarese B, Barnum G, Krause PR, Kost RG, Meier JL, Sekulovich R, Adair SF, Dekker CL: Placebo-controlled trial of vaccination with recombinant glycoprotein $D$ of herpes simplex virus type $\mathbf{2}$ for immunotherapy of genital herpes. Lancet 1994, 343:1460-1463.

20. Brown ZA: HSV-2 specific serology should be offered routinely to antenatal patients. Rev Med Virol 2000, 10:14|-| 44.

21. Wald A: New therapies and prevention strategies for genital herpes. Clin Infect Dis 1999, 28(SuppI I):S4-I3

22. Hashido M, Kawana T, Matsunaga $Y$, Inouye $S$ : Changes in prevalence of herpes simplex virus type $I$ and 2 antibodies from 1973 to 1993 in the rural districts of Japan. Microbiol Immunol $1999,43: 177-180$
23. Persson K, Mansson A, Jonsson E, Nordenfelt E: Decline of herpes simplex virus type 2 and Chlamydia trachomatis infections from 1970 to 1993 indicated by a similar change in antibody pattern. Scand I Infect Dis 1995, 27:195-199.

24. Garcia-Corbeira P, Dal Re R, Aguilar L, Granizo JJ, Garcia-de-Lomas $\mathrm{J}$ : Is sexual transmission an important pattern for herpes simplex type 2 virus seroconversion in the Spanish general population? J Med Virol 1999, 59:194-197.

25. Malkin JE, Morand P, Malvy D, Ly TD, Chanzy B, de Labareyre C, El Hasnaoui A, Hercberg S: Seroprevalence of HSV-I and HSV-2 infection in the general French population. Sex Transm Infect 2002, 78:201-203.

26. Obasi A, Mosha F, Quigley M, Sekirassa Z, Gibbs T, Munguti K, Todd J, Grosskurth H, Mayaud P, Changalucha J, Brown D, Mabey D, Hayes $\mathrm{R}$ : Antibody to herpes simplex virus type 2 as a marker of sexual risk behavior in rural Tanzania. J Infect Dis 1999, 179:16-24.

27. Laubereau B, Zwahlen M, Neuenschwander B, Heininger U, Schaad UB, Desgrandchamps D: Herpes simplex virus type $I$ and 2 in Switzerland. Schweiz Med Wochenschr 2000, I30:I43-I50.

28. Wietlisbach V, Paccaud F, Rickenbach M, Gutzwiller F: Trends in cardiovascular risk factors (1984-1993) in a Swiss region: results of three population surveys. Prev Med 1997, 26:523-533.

29. Ribes JA, Smith A, Hayes M, Baker DJ, Winters JL: Comparative performance of herpes simplex virus type I-specific serologic assays from MRL and Meridian Diagnostics. J Clin Microbiol 2002, 40:1071-1072.

30. Venables WN, Ripley BD: Tree-based methods. In Modern applied statistics with S-PLUS Edited by: Venables WN, Ripley BD. New York: Springer Verlag; 1994:329-347.

3I. Xu F, Schillinger JA, Sternberg MR, Johnson RE, Lee FK, Nahmias AJ, Markowitz LE: Seroprevalence and coinfection with herpes simplex virus type $I$ and type 2 in the United States, 19881994. I Infect Dis 2002, 185:1019-1024.

32. Hankins CA, Friedman SR, Zafar T, Strathdee SA: Transmission and prevention of HIV and sexually transmitted infections in war settings: implications for current and future armed conflicts. AIDS 2002, 16:2245-2252.

33. Breinig MK, Kingsley LA, Armstrong JA, Freeman DJ, Ho M: Epidemiology of genital herpes in Pittsburgh: serologic, sexual, and racial correlates of apparent and inapparent herpes simplex infections. I Infect Dis 1990, 162:299-305.

34. Tideman RL, Taylor J, Marks C, Seifert C, Berry G, Trudinger B, Cunningham A, Mindel A: Sexual and demographic risk factors for herpes simplex type $I$ and $\mathbf{2}$ in women attending an antenatal clinic. Sex Transm Infect 200I, 77:413-4I5

35. Dubois-Arber F, Jeannin A, Spencer B: Long term global evaluation of a national AIDS prevention strategy: the case of Switzerland. AIDS 1999, 13:257|-2582.

36. Aral SO, Holmes KK: Social ans behavioral determinants of the epidemiology of STDs: industrialized and developing countries. In Sexually Transmitted Diseases Edited by: Holmes KK, Mardh PA, Sparling PF, Lemon SM, Stamm WE, Piot P. New York: McGraw-Hill; 1999:39-76.

37. Brown ZA, Benedetti J, Ashley R, Burchett S, Selke S, Berry S, Vontver LA, Corey L: Neonatal herpes simplex virus infection in relation to asymptomatic maternal infection at the time of labor. N Engl] Med I 99I, 324: I 247-I 252.

38. Barton IG, Kinghorn GR, Najem S, Al Omar LS, Potter CW: Incidence of herpes simplex virus types $I$ and 2 isolated in patients with herpes genitalis in Sheffield. Br J Vener Dis 1982 , 58:44-47.

39. Koutsky LA, Ashley RL, Holmes KK, Stevens CE, Critchlow CW, Kiviat N, Lipinski CM, Wolner-Hanssen P, Corey L: The frequency of unrecognized type 2 herpes simplex virus infection among women. Implications for the control of genital herpes. Sex Transm Dis 1990, 17:90-94.

40. Gottlieb SL, Douglas JM Jr, Schmid DS, Bolan G, latesta M, Malotte CK, Zenilman J, Foster M, Baron AE, Steiner JF, Peterman TA, Kamb ML, Project RESPECT Study Group: Seroprevalence and correlates of herpes simplex virus type 2 infection in five sexually transmitted-disease clinics. J Infect Dis 2002, I 86: I 38I-I 389.

4I. Conde-Glez CJ, Juarez-Figueroa L, Uribe-Salas F, Hernandez-Nevarez P, Schmid DS, Calderon E, Hernandez-Avila M: Analysis of herpes simplex virus I and 2 infection in women with high risk sexual behaviour in Mexico. Int J Epidemiol 1999, 28:57I-576. 
42. Roest RW, van der Meijden WI, van Dijk G, Groen J, Mulder PG, Verjans GM, Osterhaus AD: Prevalence and association between herpes simplex virus types $I$ and 2-specific antibodies in attendees at a sexually transmitted disease clinic. Int J Epidemiol 200I, 30:580-588.

43. Bryson Y, Dillon M, Bernstein DI, Radolf J, Zakowski P, Garratty E: Risk of acquisition of genital herpes simplex virus type 2 in sex partners of persons with genital herpes: a prospective couple study. J Infect Dis 1993, 167:942-946.

44. Brown ZA, Selke S, Zeh J, Kopelman J, Maslow A, Ashley RL, Watts $\mathrm{DH}$, Berry S, Herd M, Corey L: The acquisition of herpes simplex virus during pregnancy. $N$ Engl J Med 1997, 337:509-5I5.

45. Stanberry LR, Spruance SL, Cunningham AL, Bernstein DI, Mindel A, Sacks S, Tyring S, Aoki FY, Slaoui M, Denis M, Vandepapeliere P, Dubin G, GlaxoSmithKline Herpes Vaccine Efficacy Study Group: Glycoprotein-D-adjuvant vaccine to prevent genital herpes. N Engl] Med 2002, 347:1652-166I.

46. Wald A, Langenberg AG, Link K, lzu AE, Ashley R, Warren T, Tyring $S$, Douglas JM Jr, Corey L: Effect of condoms on reducing the transmission of herpes simplex virus type 2 from men to women. JAMA 200I, 285:3100-3106.

\section{Pre-publication history}

The pre-publication history for this paper can be accessed here:

http://www.biomedcentral.com/1471-2334/4/10/prepub

Publish with Biomed Central and every scientist can read your work free of charge

"BioMed Central will be the most significant development for disseminating the results of biomedical research in our lifetime. "

Sir Paul Nurse, Cancer Research UK

Your research papers will be:

- available free of charge to the entire biomedical community

- peer reviewed and published immediately upon acceptance

- cited in PubMed and archived on PubMed Central

- yours - you keep the copyright

Submit your manuscript here:

http://www.biomedcentral.com/info/publishing_adv.asp
BioMedcentral 